\title{
Species richness and root colonization of arbuscular mycorrhizal fungi in Syngonanthus elegans, an endemic and threatened species from the Cerrado domain in Brazil
}

\section{Riqueza de espécies e colonização radicular de fungos micorrízicos arbusculares em Syngonanthus elegans, uma espécie endêmica e ameaçada do Cerrado no Brasil}

\author{
Hesmael Antonio Orlandi Costa', Sidney Luiz Stürmer², Carla Ragonezi', Paulo Henrique Grazziotti, \\ Danielle Cristina Fonseca Santos Grazziotti ${ }^{4}$, Enilson de Barros Silva ${ }^{5}$
}

\author{
'Universidade Federal dos Vales do Jequitinhonha e Mucuri/UFVJM, Laboratório de Microbiologia do Solo, Diamantina, MG, Brasil \\ 2Universidade Regional de Blumenau/FURB, Departamento de Ciências Naturais, Blumenau, SC, Brasil \\ ${ }^{3}$ Universidade Federal dos Vales do Jequitinhonha e Mucuri/UFVJM, Departamento de Engenharia Florestal, Diamantina, MG, Brasil \\ ${ }^{4}$ Instituto de Desenvolvimento do Norte e Nordeste de Minas Gerais/IDENE, Diamantina, MG, Brasil \\ 5Universidade Federal dos Vales do Jequitinhonha e Mucuri/UFVJM, Departamento de Agronomia, Diamantina, MG, Brasil \\ *Corresponding author: grazziot@yahoo.com.br \\ Received in december 11, 2015 and approved in march 11, 2016
}

\begin{abstract}
Syngonanthus elegans is an endangered plant species occurring in the Brazilian Cerrado whose interaction with arbuscular mycorrhizal fungi (AMF) is poorly understood. The aim of this work was to evaluate the occurrence of AMF species and mycorrhizal colonization of S. elegans in two sampling areas named "Soberbo" stream (Soberbo) and "Parque Nacional das Sempre-Vivas" (Park), both found in Diamantina-MG, Brazil. In each area, one plot $(100 \times 100 \mathrm{~m})$ was established, and roots and soil samples near the roots were collected from 10 plants in each plot. Further sampling included three specimens each of Loudetiopsis chrysothrix and Xyris sp.. Typical mycorrhizal colonization structures were observed in S. elegans roots, and colonization was measured at 75\%. Considering both sites and all three hosts, 26 AMF species were recovered, 8 of which were identified only at the genus level. Glomus sp. 1, Scutellospora pernambucana, Acaulospora cavernata and Acaulospora mellea were classified as dominant in both areas. Other species were also considered dominant, including Glomus sp. 4 in Soberbo and Dentiscutata biornata and Gigaspora albida in Park. Trap cultures revealed the presence of seven additional species. For S. elegans, AMF species richness was slightly higher in Park than in Soberbo. Simpson diversity and evenness were slightly higher in Soberbo for S. elegans-associated AMF communities. Overall, S. elegans is highly colonized by arbuscular mycorrhizal fungi and is associated with a wide range of AMF species in the field, suggesting that this association is important for the establishment and survival of this threatened species. Some of the observed species may be new to science.
\end{abstract}

Index terms: Fungal diversity; star flowers; Rupestrian fields.

\begin{abstract}
RESUMO
Syngonanthus elegans é uma espécie vegetal em vias de extinção que ocorrem no Cerrado brasileiro, cuja interação com fungos micorrízicos arbusculares (FMA) é deficientemente compreendida. O objetivo deste trabalho foi avaliar a ocorrência de espécies de FMA e colonização micorrízica de S. elegans. Em duas áreas de amostragem denominadas Córrego do Soberbo (Soberbo) e Parque Nacional das Sempre-Vivas (Parque), ambas localizadas em Diamantina-MG, Brasil, uma parcela de 100 × 100 m foi estabelecida e solo da rizosfera e raízes foram coletados de 10 plantas em cada parcela. Além disso, amostragem incluiu três espécimes de cada Loudetiopsis chrysothrix e Xyris sp.. Estruturas típicas de colonização micorrízica foram observadas nas raízes de $S$. elegans e a colonização medida foi de $75 \%$. Considerando as duas áreas e os três hospedeiros, 26 espécies de FMA foram recuperados, 8 delas identificadas apenas até gênero. Glomus sp. 1, Scutellospora pernambucana, Acaulospora cavernata e Acaulospora mellea foram classificados como dominantes em ambas as áreas. Além dessas, também foram consideradas dominantes Glomus sp. 4 em Soberbo, e Dentiscutata biornata e Gigaspora albida no Parque. Culturas armadilhas revelaram a presença de sete espécies adicionais. Para S. elegans, a riqueza de espécies de FMA foi ligeiramente superior no Parque do que no Soberbo. Diversidade de Simpson e equitabilidade foram ligeiramente maiores no Soberbo para as comunidades de FMA associados com S. elegans. S. elegans é altamente colonizadas por fungos micorrízicos arbusculares e associada a uma grande variedade de espécies de FMA em condições de campo, sugerindo que essa associação é importante para o estabelecimento e sobrevivência desta espécie ameaçada. Algumas espécies observadas podem ser novas para a ciência.
\end{abstract}

Termos para indexação: Diversidade fúngica; sempre-vivas; Campos Rupestres.

\section{INTRODUCTION}

Syngonanthus species (Eriocaulaceae) are known as star flowers or everlasting plants because their inflorescence and scapes maintain their form and color even long after harvesting (Borba; Amorim, 2007; Miranda; Giulietti, 2001). These properties contribute to star flowers being 
harvested and exported for ornamental purposes (Giulietti et al., 1996; Nunes et al., 2008). Syngonanthus elegans (Bong.) Ruhland, the gold feet everlasting plant, is one of the most valuable star flowers species due to its long golden scape, which is used for handmade crafts. Plants of this species are harvested by local communities in an extractivist way as an alternative source of revenue, leading this species to be considered at risk of extinction (Borba; Amorim, 2007; Menezes; Giulietti, 2000).

S. elegans is an endemic of the Rupestrian fields or Rupestrian grasslands, a unique ecoregion that covers portions of the southeastern Brazilian mountains in the transition between the Atlantic rain forest and the Cerrado domains. This ecoregion is one of the most endangered ecosystems in the world, occurring in altitudes above $900 \mathrm{~m}$ with rocky areas, shallow soils, sandy plateaus and experiencing drought periods alternated with hydric soil saturation (Joly, 1970; Giulietti; Pirani; Harley, 1997; Menezes; Giulietti, 2000; Conceição; Pirani, 2007). Estimates suggest that $30 \%$ of the Rupestrian fields plant taxa are restricted to this ecoregion, which is mainly dominated by Eriocaulaceae, Poaceae, Cyperaceae, Xyridaceae, Velloziaceae, Orchidaceae, and Melastomataceae (Conceição, Pirani, 2005; Costa, 2005; Carvalho et al., 2014; Zappi; Taylor, 2003). Some species belonging to the Eriocaulaceae family, such as S. elegans, $S$. aurifibratus Silveira and $S$. lineares Ruhland, have developed strategies to minimize water loss through mucilage production in the root system (Scatena; Menezes, 1996). This mucilage possibly favors the relationship of these plants with soil microorganisms such as associative bacteria and fungi including arbuscular mycorrhizal fungi (AMF).

Considering the well-established fact that AMF enhances plant nutrient uptake in low-fertility soils when associated with plant roots, mycorrhizal association in $S$. elegans might represent a strategy to cope with the harsh and poor soil conditions of Rupestrian fields. Mycorrhizal associations of native species growing in this region are poorly understood, but recently, studies focusing on AMF diversity in distinct habitats within Rupestrian fields (Carvalho et al., 2012) and assessing the mycorrhizal status of some plant species (Pagano; Cabello, 2012) have been developed, contributing to management conservation programs for this ecoregion (Fernanda; Echeverría; Pagano, 2012).

The occurrence of mycorrhizal association in endemic plants has been reported previously in the literature (Bashan et al., 2007; Koske; Gemma; Flynn, 1992; Koske; Gemma, 2002; Silva et al., 2001), however, reports on the mycorrhizal status of Eriocaulaceae plants are scarce. Mycorrhizal colonization up to $20 \%$ was registered in Tonina fluviatilis Aubl. (Silva et al., 2001), and the occurrence of colonization by six Glomus species was observed in Syngonanthus mucugensis Giulietti and Syngonanthus curralensis Moldenke (Borba; Amorim, 2007). Although some progress has been achieved regarding knowledge of biological systems in Rupestrian fields, there is a general lack of information regarding interactions between soil microorganisms and plants in this ecoregion. To the best of the authors' knowledge, no information regarding AMF occurrence and colonization associated with $S$. elegans has been published. In this study, our goal was to evaluate root mycorrhizal colonization the occurrence and species richness of AMF associated with S. elegans occurring in two Rupestrian field areas.

\section{MATERIAL AND METHODS}

\section{Study area}

The study area was localized in the meridional portion of the "Serra do Espinhaço", Minas Gerais state, southeastern Brazil and is characterized by the presence of Rupestrian fields. Climate in this area is mesothermic (Cwb according to Köppen) and is characterized by moderate and humid summers and cold and dry winters (Neves; Abreu; Fraga, 2005). The average annual temperature is $18.3{ }^{\circ} \mathrm{C}$, and average annual precipitation is $1.404 \mathrm{~mm}$, with $88 \%$ of the total annual precipitation occurring during the rainy season from October to March (Vieira et al., 2010). To increase the detection capability of AMF diversity, two sampling sites that were $40 \mathrm{Km}$ apart from one another were selected for this study in the municipality of Diamantina, Minas Gerais. One site was located near the headspring of the Soberbo stream, here identified as Soberbo, within the Juscelino Kubitschek campus of the Universidade Federal dos Vales do Jequitinhonha e Mucuri $\left(18^{\circ} 12^{\prime} 21.1^{\prime \prime} \mathrm{S} 43^{\circ} 33^{\prime} 47.6^{\prime \prime} \mathrm{W}\right)$ at an altitude of $1.368 \mathrm{~m}$. The other site was in the National Park "Parque Nacional das Sempre-vivas", here referred to as Park ( $17^{\circ} 55^{\prime} 02.9^{\prime \prime} \mathrm{S}$ $43^{\circ} 47^{`} 11.2^{\prime \prime} \mathrm{W}$ ) with an altitude of $1.310 \mathrm{~m}$. Soils in both sites were classified as typic quartzipsamment according to Empresa Brasileira de Pesquisa Agropecuária - Embrapa (2006), which correspond to Entisols according to Soil Survey Staff (1999).

\section{Study design and sampling}

One plot $(100 \times 100 \mathrm{~m})$ was established within each site, and roots along with soil samples near the roots were collected from 10 specimens of $S$. elegans during the dry season. Three specimens each of Loudetiopsis chrysothrix (Nees) Conert (Poaceae) and Xyris sp. 
(Xyridaceae) were also sampled for comparison (control). Soil samples were stored in plastic bags and kept in thermo boxes until transportation to the laboratory and stored at $4{ }^{\circ} \mathrm{C}$ until analysis. A composite soil sample from each area was sent to the laboratory for chemical and physical analysis (Table 1).

Roots were washed under tap water, cut in 1-2 cm fragments and stored in a 50\% alcohol solution. Roots were stained according to Phillips and Hayman (1970) with modifications in the bleaching step. For this, roots were placed in a $10 \% \mathrm{KOH}$ solution for $30 \mathrm{~min}$. This procedure was repeated three times; the roots were subjected to a $70^{\circ} \mathrm{C}$ water bath for two min during the third repeat of the procedure. The percentage of colonized root length by AMF was evaluated according to the grid-line method proposed by Giovannetti and Mosse (1980).

From each soil sample, a $50 \mathrm{~g}$ aliquot of soil was used to extract AMF spores using the wet sieving method (Gerdemann; Nicolson, 1963) and two stacked sieves with $710 \mu \mathrm{m}$ and $45 \mu \mathrm{m}$ openings, followed by sucrose gradient centrifugation ( $20 \%$ and $60 \%$ ). Spores were then separated by morphotypes and counted under a dissecting microscope. For identification, spores were placed on glass slides in polyvinyl alcohol-lactic acid glycerin (PVLG) with PVLG + Melzer's reagent as the mounting media. AMF species were identified based on the subcellular structures of asexual spores following descriptions of living reference cultures at INVAM (http://invam.caf.wvu. edu), and by comparison with original species description protocols. Classification of AMF into families and genera followed that of Redecker et al. (2013).

To recover AMF species that were not sporulating at the sampling time, trap cultures were established according to Stutz and Morton (1996). For each plant species, three pots of trap cultures were established by mixing $750 \mathrm{~g}$ of field soil with sterilized sand $(3 \times$ at $121{ }^{\circ} \mathrm{C}$ for $60 \mathrm{~min}$ ). This mixture was placed in $1.6 \mathrm{~L}$ pots and sown with 20 seeds of Brachiaria brizantha (superficially disinfected with $70 \%$ alcohol for $2 \mathrm{~min}$ and $1 \%$ sodium hypochlorite for $1 \mathrm{~min}$ ). Plants were kept under greenhouse conditions and watered daily if necessary. Every two weeks each pot received 20 $\mathrm{mL}$ of Hoagland's (Hoagland; Arnon, 1950) nutrient solution without phosphorus. After 3 months, plants were allowed to dry out in situ by suspending watering. Then, shoots and the top $2 \mathrm{~cm}$ of substrate from each pot were discarded. The remaining content of each pot was thoroughly homogenized and $50 \mathrm{~g}$ used to extract and identify AMF spores as previously described.

Frequency of occurrence $\left(\mathrm{F}_{\mathrm{i}}\right)$ for each AMF species was calculated according to the equation $\mathrm{F}_{\mathrm{i}}=$ $\left(\mathrm{J}_{\mathrm{i}} / \mathrm{K}\right)^{*} 100$, where $\mathrm{F}_{\mathrm{i}}$ is the frequency of occurrence of species " $i$ ", $J_{i}$ represents the number of samples that species " $\mathrm{i}$ " was present, and $\mathrm{K}$ is the total number of samples for each site (Brower; Zar; Von Ende, 1998). According to the frequency of occurrence, AMF species were classified as dominant (D) $\left(\mathrm{F}_{\mathrm{i}}>50 \%\right)$, most common (MC) $\left(30 \%<\mathrm{F}_{\mathrm{i}} \leq 50 \%\right)$, common (C) $(10 \%$ $\left.<\mathrm{F}_{\mathrm{i}} \leq 30 \%\right)$, and rare $(\mathrm{R})\left(\mathrm{F}_{\mathrm{i}} \leq 10 \%\right)$ (Zhang; Gui; Liu, 2004). Species richness was obtained from the number of AMF species, and spore abundance of each species was used to calculate diversity indices according to Magurran (1988). Simpson diversity indices were calculated using the equation 1-Is, where: Is $=\Sigma n_{i}\left(n_{i}-1\right) / N(N-1)$, with $n_{i}$ being the number of individuals of each species and $N$ the total number of individuals. Simpson dominance indices were calculated using the equation $\Sigma\left(n_{i} / N\right)^{2}$. The Pielou evenness index was obtained using the equation $\mathrm{H}^{\top} / \mathrm{ln}$ (S), wherein $\mathrm{H}^{`}=-\Sigma p_{i} \ln p_{i}$ e $p_{i}=\mathrm{n}_{\mathrm{i}} / \mathrm{N}$ and $\mathrm{S}$ is the total number of species.

\section{Statistical analysis}

The number of spores and percentage of colonized root length by AMF were transformed using $\ln (\mathrm{x}+1)$ because they do not follow a normal distribution. The number of spores between areas was submitted to an analysis of variance (ANOVA).

Table 1: Soil characteristics from sampling sites Soberbo and Park in Diamantina, MG, Brazil.

\begin{tabular}{|c|c|c|c|c|c|c|c|c|c|c|c|c|}
\hline & $\mathrm{pH}$ & $P^{1}$ & $\mathrm{~K}^{1}$ & $\mathrm{Ca}^{2}$ & $\mathrm{Mg}^{2}$ & $\mathrm{Al}^{2}$ & $\mathrm{~m}^{3}$ & $v^{3}$ & Moisture & $\mathrm{OM}^{3}$ & Sand & Clay \\
\hline & \multicolumn{6}{|c|}{----mg dm-3---- } & \multicolumn{3}{|c|}{-----------'\%----------- } & \multicolumn{3}{|c|}{--------Dag Kg-1----- } \\
\hline Soberbo & 4.6 & 5.8 & 13 & 0.5 & 0.3 & 0.2 & 19 & 37 & 3.5 & 0.2 & 91 & 6 \\
\hline Park & 5.0 & 2.4 & 4 & 0.7 & 0.4 & 0.3 & 21 & 48 & 0.6 & 0.1 & 91 & 1 \\
\hline
\end{tabular}

${ }^{1} \mathrm{P}$ and $\mathrm{K}$ (extracted by Mehlich I).

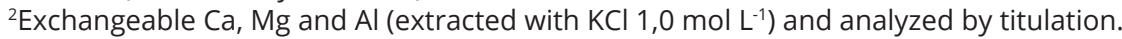

${ }^{3} \mathrm{~m}=$ aluminum saturation, $\mathrm{v}=$ base saturation, $\mathrm{OM}=$ organic matter. 


\section{RESULTS AND DISCUSSION}

Roots of $S$. elegans were colonized by typical mycorrhizal structures such as hyphae, vesicles and arbuscules. Percentage of mycorrhizal root lengths in $S$. elegans averaged $75 \%$, and no differences were detected between plants in Soberbo and Park $(\mathrm{P}<0.05)$. Root colonization of L. chrysothrix and Xyris sp. averaged $87 \%$ and $76 \%$, respectively. This work represents the first report in the literature relating the occurrence of arbuscular mycorrhiza in S. elegans, L. chrysothrix and Xyris sp.. Analysis of the root system showed typical arbuscular mycorrhizal structures including arbuscules, vesicles and internal mycelium and a percentage of mycorrhizal root colonization ranging from 75 to $87 \%$. Based on these high levels of mycorrhizal colonization in the field, these plants can be considered mycotrophic. Levels of mycorrhizal colonization in all three hosts were relatively high compared with other species in the Eriocaulaceae. For example, 20\% of root colonization was measured in Tonina fluviatilis (Silva et al., 2001) and up to 67\% in Paepalanthus bromelioides (Pagano; Scotti, 2009). The low nutrient content in soils (Table 1) and the mild climate (average annual temperature between 19 and $18^{\circ} \mathrm{C}$ ) of the studied areas may contribute to a low rooting turnover that results in high colonization levels. In low-fertility soils, plants usually maintain high levels of arbuscular mycorrhizal colonization (Powers; Treseder; Lerdau, 2005; Saggin Júnior et al., 1995; Treseder, 2004). The similar values of root mycorrhizal colonization between Soberbo and Park may be explained by their similar soil properties, climate and altitude.

A total of 23 AMF species were detected in the soil samples near roots of $S$. elegans, and the number of species was slightly higher at Park (20 species) than at Soberbo (16 species) (Table 2). AMF species richness in soil under $S$. elegans tended to be higher than under L. chrysothrix and Xyris sp.. This AMF species richness associated with S. elegans can be considered relatively high (Table 2) compared with other Syngonanthus species. Only six AMF species were associated with $S$. mucugensis and four species with $S$. curralensis, both of which also occur in the "Serra do Espinhaço Meridional" in Bahia state, Brazil (Borba, Amorim, 2007). Comparing our results with those found in other endemic plants species, AMF species richness associated with $S$. elegans was of the same magnitude as that detected in Fouquieria columnaris (Kell) Kell. (23 species) endemics of Mexico (Bashan et al., 2007), and 5-6-fold that of other registered endemic plants such as Dubautia menziesii (A. Gray) Keck D (4 species) (Koske; Gemma, 2002) and P. bromelioides (3 species) (Pagano; Scotti, 2009).
We attributed this high species richness associated with $S$. elegans to our sampling strategy (ten plants in two locations) and the use of trap cultures. Trap cultures are important to trigger AMF sporulation, especially in environments with hydric scarcity such as Rupestrian fields. Stutz and Morton (1996) observed that AMF species richness from a desert environment was comparable to that detected from mesic environments and hypothesized that trap cultures provide a more homogenous and constant environment that favors AMF sporulation (Stutz; Morton, 1996). Considering that Rupestrian fields experience periods of water scarcity and that our sampling was conducted during the dry season, the trap culture environment certainly acted as a promoter of AMF sporulation.

Across both sites and all three hosts, a total of 26 AMF species was recovered (Table 2). Eight of these species could be identified only to the genus level and putatively represent new species for science. Some of the nonidentified species produced very few spores, precluding a more thorough comparison to delimit species. The presence of unknown species in Brazilian ecosystems is common, where $20-26 \%$ of AMF species in many surveys are not identified (Stürmer; Siqueira, 2006). Rupestrian fields represent an ecosystem with a high endemism for plant species (Conceição; Pirani, 2007) that could be associated with unique AMF species and may be considered a hotspot for this group of fungi (Carvalho et al., 2012).

Glomus microagregatum, Acaulospora morrowiae, and Scutellospora calospora were recovered exclusively from trap cultures established with soils taken under $S$. elegans and Xyris sp. (Table 2). Other species recovered in trap cultures but also detected under field conditions included Racocetra verrucosa, Scutellospora sp. 1, Glomus sp. 4, Gigaspora albida, and Ambispora leptoticha (Table 2).

In the field, S. elegans was associated with AMF belonging to Gigasporaceae, Acaulosporaceae, Glomeraceae and Ambisporaceae, with the last family detected only in Soberbo (Table 2). The proportion of species per family differed between both areas (Figure 1a). In Soberbo, Acaulosporaceae represented $47 \%$ of the total number of species recovered, while in Park, species were evenly distributed among Gigasporaceae (33\%), Acaulosporaceae (29\%) and Glomeraceae $(29 \%)$. Despite the higher number of Acaulosporaceae in Soberbo, the AMF community associated with $S$. elegans was evenly dominated by the three main families of Glomeromycota (Table 2, Figure 1a), which contrasts with the AMF communities detected under $S$. mucugensis and $S$. curralensis that were dominated by members of Glomeraceae (Borba; Amorim, 2007). However, 
Table 2: Occurrence of AMF species detected in soil samples near roots and trap cultures $\left(^{*}\right)$ of S. elegans, L. chrysothrix and Xyris sp. at the Soberbo and Park sites in Diamantina, MG, Brazil.

\begin{tabular}{|c|c|c|c|c|c|c|}
\hline \multirow{2}{*}{ AMF species } & \multicolumn{3}{|c|}{ Soberbo } & \multicolumn{3}{|c|}{ Park } \\
\hline & S. elegans & L. chrysothrix & Xyris sp. & S. elegans & L. chrysothrix & Xyris sp. \\
\hline \multicolumn{7}{|l|}{ Gigasporaceae } \\
\hline $\begin{array}{l}\text { Dentiscutata biornata (Spain, Sieverd. \& S. } \\
\text { Toro) Sieverd., F.A.Souza \& Oehl }\end{array}$ & $\mathrm{x}$ & & $\mathrm{x}$ & $x$ & $\mathrm{x}$ & $\mathrm{x}$ \\
\hline $\begin{array}{l}\text { Dentiscutata heterogama (T.H Nicolson \& } \\
\text { Gerd.) Sieverd., F.A. Souza \& Oehl }\end{array}$ & & & & $x$ & & $x$ \\
\hline $\begin{array}{l}\text { Dentiscutata reticulata (Koske, D.D. Mill. \& } \\
\text { C. Walker) Sieverd., F.A. Souza \& Oehl }\end{array}$ & & & $x$ & & & \\
\hline $\begin{array}{l}\text { Racocetra verrucosa (Koske \& C. Walker) } \\
\text { Oehl, F.A.Souza \& Sieverd }\end{array}$ & & & & $x$ & & $x^{*}$ \\
\hline $\begin{array}{l}\text { Racocetra fulgida (Koske \& C. Walker) } \\
\text { Oehl, F.A. Souza \& Sieverd. }\end{array}$ & & $x$ & & & $x$ & \\
\hline $\begin{array}{l}\text { Scutellospora calospora (Nicol.\& Gerd.) C. } \\
\text { Walker \& F.E. Sanders }\end{array}$ & & & & & & $X^{*}$ \\
\hline $\begin{array}{l}\text { Scutellospora pernambucana Oehl, D.K } \\
\text { Silva, N. Freitas, L.C. Maia }\end{array}$ & $x$ & $x$ & $x$ & $x$ & $x$ & $x$ \\
\hline Scutellospora sp. 1 & $x$ & & $x$ & $x^{*}$ & & \\
\hline Gigaspora decipiens Hall \& Abbot & & & & $x$ & $x$ & $x$ \\
\hline Gigaspora albida N.C. Schenck \& G.S. Sm. & & & & $\mathrm{x}$ & $x^{*}$ & \\
\hline \multicolumn{7}{|l|}{ Acaulosporaceae } \\
\hline Acaulospora scrobiculata Trappe & $x$ & & $x$ & $x$ & & \\
\hline $\begin{array}{l}\text { Acaulospora morrowiae Spain \& } \\
\text { N.C.Schenck }\end{array}$ & $x^{*}$ & & & $x^{*}$ & & $x^{*}$ \\
\hline Acaulospora cavernata Blaszk. & $x$ & $x$ & $x$ & $x$ & $x$ & $x$ \\
\hline $\begin{array}{l}\text { Acaulospora herrerae cf. Furrazola, B.T. } \\
\text { Goto, G.A. Silva, Sieverd. \& Oehl }\end{array}$ & $x$ & & & $x$ & & \\
\hline $\begin{array}{l}\text { Acaulospora entreriana cf. M.S. Velázquez } \\
\text { \& Cabello }\end{array}$ & $x$ & & & & & \\
\hline Acaulospora mellea Spain \& Schenck & $x$ & $x$ & $x$ & $x$ & $x$ & $x$ \\
\hline Acaulospora sp. 1 & $x$ & & & & & \\
\hline Acaulospora sp. 2 & $x$ & & & $x$ & & \\
\hline \multicolumn{7}{|l|}{ Glomeraceae } \\
\hline $\begin{array}{l}\text { Rhizophagus clarus (Nicolson \& } \\
\text { Schenck) C. Walker \& A. Schüssler }\end{array}$ & & & & $x$ & & \\
\hline $\begin{array}{l}\text { Glomus microagregatum Koske, Gemma } \\
\text { \& Olexia }\end{array}$ & & & & $x^{*}$ & & \\
\hline Glomus sp. 1 & $x$ & $x$ & $x$ & $x$ & $x$ & $x$ \\
\hline Glomus sp. 2 & $x$ & & $x$ & & & \\
\hline Glomus sp. 3 & $x$ & & & $x$ & & \\
\hline Glomus sp. 4 & $x$ & & $x^{*}$ & $x$ & & $x^{*}$ \\
\hline Glomus sp. 5 & & $x$ & & $x$ & & \\
\hline \multicolumn{7}{|l|}{ Ambisporaceae } \\
\hline $\begin{array}{l}\text { Ambispora leptoticha (N.C. Schenck \& G.S. } \\
\text { Sm.) R.J. Bills \& J.B. Morton }\end{array}$ & $x$ & & & $x^{*}$ & & \\
\hline Species total & 16 & 6 & 10 & 20 & 8 & 11 \\
\hline
\end{tabular}


this does agree with a survey of a mosaic of habitats in Rupestrian fields that were dominated by Glomeraceae, Acaulosporaceae, and Gigasporaceae (Carvalho et al., 2012). Soil pH in Soberbo and Park were 4.6 and 5.0, respectively (Table 1), and this soil factor could have favored dominance of Acaulosporaceae and Glomeraceae, as organisms pertaining to both families are often found in soil with a pH from 4.0 to 6.0 (Oehl et al., 2006; Silveira, Souza; Koller, 2002; Stürmer, 1999). Other studies in Rupestrian fields mentioned above recorded either zero (Borba; Amorim, 2007) or 12 species of Gigasporaceae (Borba; Amorim, 2007; Carvalho et al., 2012), while our study detected four genera and 10 species from this family (Table 2), suggesting that members of this family are also important components of the mycorrhizal community associated with $S$. elegans.

Genera associated with $S$. elegans included Dentiscutata, Racocetra, Scutellospora, Gigaspora, Acaulospora, Rhizophagus, Glomus and Ambispora (Figure 1b). Three and five S. elegans-associated species were found exclusively in Soberbo and Park, respectively (Table 2). Acaulospora and Glomus accounted for most of the AMF species in both areas (Figure 1b). It is interesting to note that AMF species associated with $S$. elegans came from four families (Table 2, Figure 1a) and eight genera (Table 2, Figure 1b) of Glomeromycota, spanning all major monophyletic clades within the phylum, suggesting that the environmental conditions of Rupestrian fields do not restrict fungal taxa establishment once they arrive at these sites. Considering the consensus classification of (Redecker et al., 2013), eight out of 18 genera and four out of 9 families of AMF were detected herein.

The number of AMF spores observed in soil samples near roots of all three hosts varied from 11 to 390 in $50 \mathrm{~g}$ of soil, with the largest number found under $S$. elegans at Soberbo and the smallest value in Xyris sp. at Park (Figure 2). AMF spores number recovered from soil samples near roots of $S$. elegans was significantly higher in Soberbo (390 spores per $50 \mathrm{~g}$ of soil) compared to Park (245 spores per $50 \mathrm{~g}$ soil) $(\mathrm{P}<0.05)$ (Figure 2$)$. The same tendency was observed for L. chrysothrix and Xyris sp.. This trend of recovering a higher number of spores in Soberbo compared to Park (Table 3, Figure 2) is intriguing considering that the host identity and sampling time were the same in both areas. We have no explanation for this pattern, but we speculate that the higher humidity in Soberbo (Table 1) could have favored AMF sporulation. The number of AMF spores associated with S. elegans (Table 3, Figure 2) can be considered high compared to other plants from the same family occurring in the same ecoregion. A total of 121 spores per $50 \mathrm{~g}$ soil were recovered under $S$. curralensis growing in the "Serra do Espinhaço Meridional" in Bahia state (Borba; Amorim, 2007) and 39-70 spores per $50 \mathrm{~g}$ soil were detected in $P$. bromelioides in the "Serra do Cipó" Minas Gerais state (Pagano; Scotti, 2009). We acknowledge that our results are from one sampling time only, but this indicates that $S$. elegans supports high sporulation and diversity of AMF.
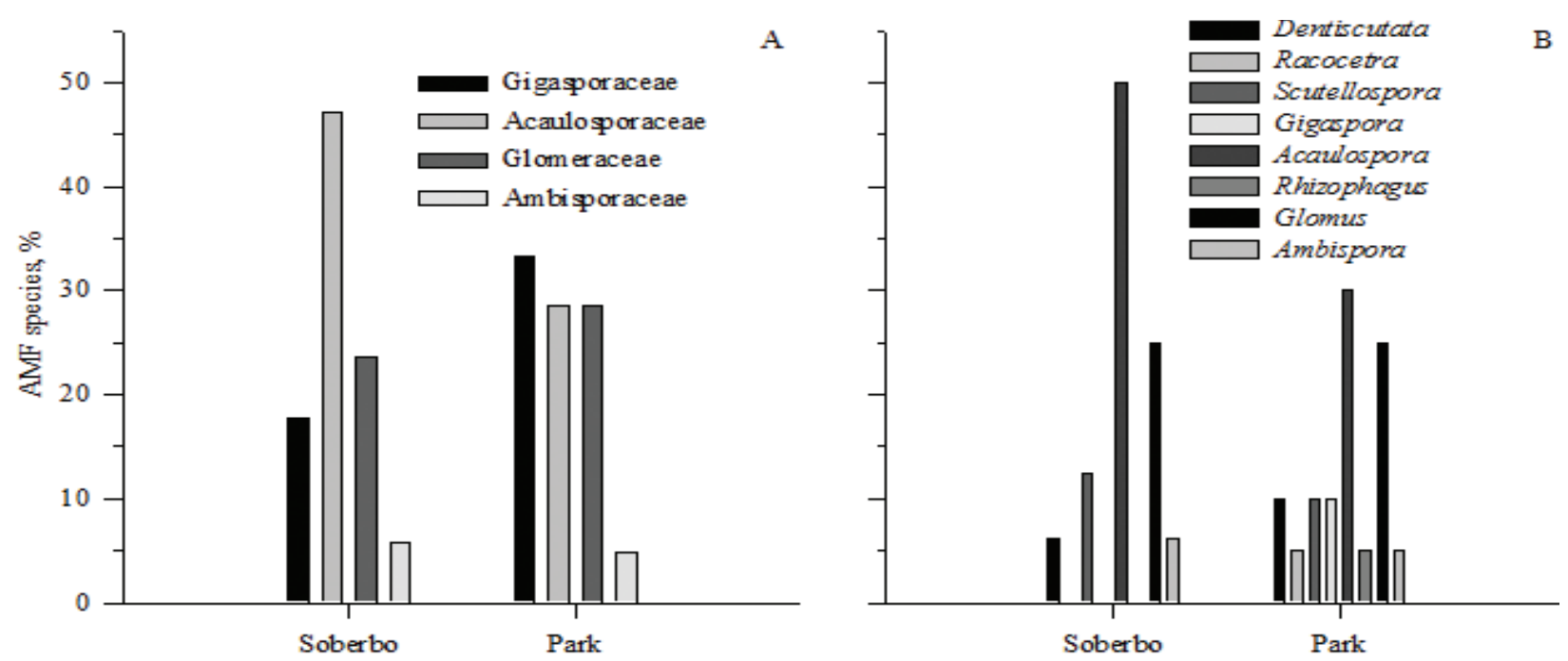

Figure 1: Families and genera of arbuscular mycorrhizal fungi associated with S. elegans at the Soberbo and Park sites. Proportion of AMF species per family (a), proportion of AMF species per genus (b). 


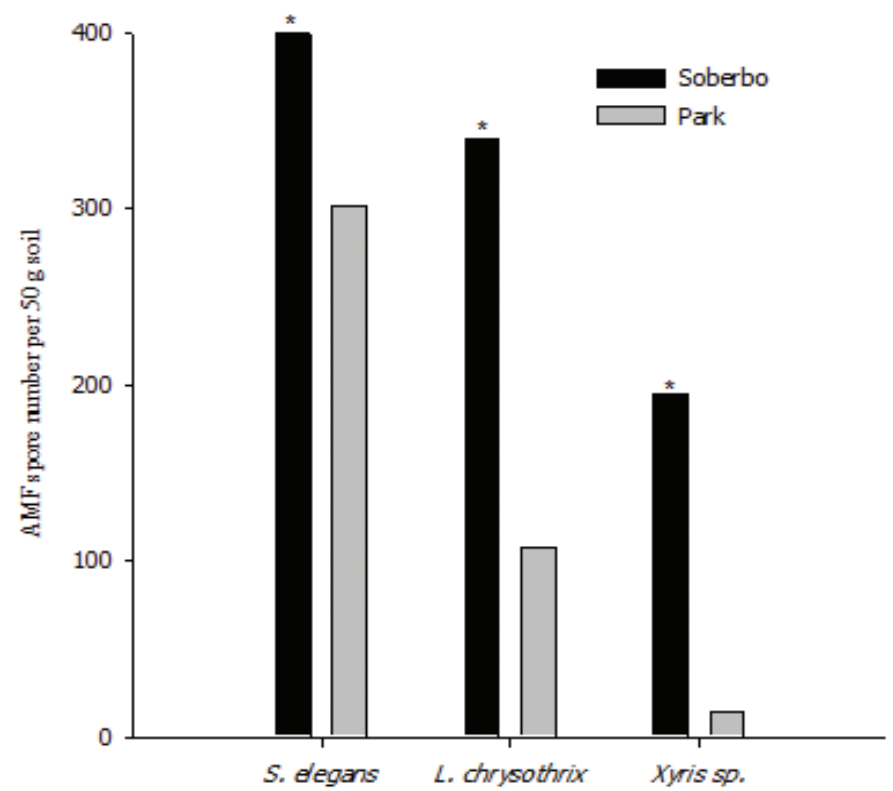

Figure 2: AMF spores (in $50 \mathrm{~g}$ soil) recovered from soil samples near roots of S. elegans $(\mathrm{n}=10), \mathrm{L}$. chrysothrix $(\mathrm{n}$ $=3)$, and Xyris sp. $(n=3)$ in the Soberbo and Park sites in Diamantina, MG. * = Differences between areas were significant at $5 \%$ as determined by an " $\mathrm{F}$ " test

Most field-produced spores in both sites pertained to Glomus sp. 1, Acaulospora cavernata, and Scutellospora pernambucana, which together accounted for $58.5 \%$ and $66.2 \%$ of the total number of spores in Soberbo and in Park, respectively (Table 3 ). This result indicates that host identity and environmental conditions work together to influence sporulation of AMF species in Rupestrian fields, and comparative studies such as this one are important to elucidate biotic and abiotic factors that influence the auto-ecology of AMF species. This dominance by three species in the community structure has been identified in other Brazilian ecosystems in different habitats such as sand dunes, tropical forest, Cerrado, and agro-ecosystems and is also based on field-collected spores (Stürmer; Siqueira, 2006). Molecular data also indicates that species abundance of AMF in natural communities follows the log normal and broken stick model, where communities are dominated by a few species (Dumbrell et al., 2010). Aside from those species, others dominant species were Acaulospora mellea in both sites, Glomus sp. 4 in Soberbo, and Dentiscutata biornata and G. albida in Park (Table 3). Most species were classified as common in both sites, and rare species occurred mostly in Park (Table 3).

For S. elegans, AMF species richness was slightly higher in Park than in Soberbo. Simpson diversity and evenness were slightly higher in Soberbo for AMF communities associated with $S$. elegans, while both indices were higher in Park for L. chrysotrhis and Xyris sp. (Figure 3). Simpson dominance was higher in Park for $S$. elegans and in Soberbo for the other hosts.

Rupestrian fields are extremely fragile environments with low or no resilience to recover after disturbance (Le Stradic et al., 2014; Le Stradic; Buisson; Fernandes, 2014). Surveys of soil microorganisms such as diazotrophic bacteria (Marra et al., 2012) and arbuscular mycorrhizal fungi as reported here are the first step to understanding microbial diversity that provides ecosystem services important for the conservation and maintenance of Rupestrian fields. This work contributed to our knowledge of mycorrhizal status and AMF species richness associated with S. elegans, an important endemic and threatened species of Rupestrian fields. In Brazil, despite the large number of endemic plant species, there is a general lack of information concerning the association of these species with arbuscular mycorrhizal fungi. Rupestrian fields shelter $23 \%$ of AMF species described across the world and $41 \%$ of identified species in Brazilian ecosystems (Stürmer; Siqueira, 2008; Souza et al., 2010). Efforts to isolate and cultivate AMF species from Rupestrian fields and further tests on their effects on growth of S. elegans will contribute to the improvement commercial cultivation of this economically important plant and help preserve its population in the ecosystem. 
Table 3: Number of spores (50 g soil) and frequency of occurrence (Fi) of AMF species from soil samples near roots of S. elegans in Soberbo and Park.

\begin{tabular}{|c|c|c|c|c|}
\hline \multirow{2}{*}{ AMF species } & \multicolumn{2}{|c|}{ Soberbo } & \multicolumn{2}{|c|}{ Park } \\
\hline & $\mathrm{N}^{\circ}$ of spores & Frequency (\%) & $\mathrm{N}^{\circ}$ of spores & Frequency (\%) \\
\hline \multicolumn{5}{|l|}{ Gigasporaceae } \\
\hline Dentiscutata biornata & 3 & $10(\mathrm{R}) 1$ & 8 & 80 (D) \\
\hline Dentiscutata heterogama & - & - & 5 & $30(C)$ \\
\hline Racocetra verrucosa & - & - & 1 & $10(\mathrm{R})$ \\
\hline Scutellospora pernambucana & 85 & $100(D)$ & 43 & $100(D)$ \\
\hline Scutellospora sp. 1 & 4 & $20(C)$ & - & - \\
\hline Gigaspora decipiens & - & - & 1 & $20(C)$ \\
\hline Gigaspora albida & - & - & 2 & $70(\mathrm{D})$ \\
\hline \multicolumn{5}{|l|}{ Acaulosporaceae } \\
\hline Acaulospora scrobiculata & - & - & 46 & $50(\mathrm{MC})$ \\
\hline Acaulospora cavernata & 88 & $100(D)$ & 42 & $80(\mathrm{D})$ \\
\hline Acaulospora herrerae cf. & 2 & $20(C)$ & 1 & $20(C)$ \\
\hline Acaulospora entreraiana cf. & 84 & $50(\mathrm{MC})$ & - & - \\
\hline Acaulospora mellea & 66 & $60(D)$ & 21 & $100(D)$ \\
\hline Acaulospora sp. 1 & 2 & $30(C)$ & - & \\
\hline Acaulospora sp. 2 & 18 & $60(D)$ & 3 & $20(C)$ \\
\hline \multicolumn{5}{|l|}{ Glomeraceae } \\
\hline Rhizophagus clarus & - & - & 1 & $30(C)$ \\
\hline Glomus sp.1 & 116 & $100(D)$ & 115 & $100(D)$ \\
\hline Glomus sp. 2 & 2 & $30(C)$ & - & - \\
\hline Glomus sp. 3 & 3 & $50(\mathrm{MC})$ & 4 & $20(C)$ \\
\hline Glomus sp.4 & 16 & $70(D)$ & 3 & $10(R)$ \\
\hline Glomus sp. 5 & - & - & 6 & $10(R)$ \\
\hline \multicolumn{5}{|l|}{ Ambisporaceae } \\
\hline Ambispora leptoticha & 5 & 40 (MC) & - & - \\
\hline
\end{tabular}

${ }^{1}$ Classification according to the frequency of occurrence of AMF species: dominant (D) $=\mathrm{Fi}>50 \%$, most common (MC) $=30 \%<$ $\mathrm{Fi} \leq 50 \%$, common $(\mathrm{C})=10 \%<\mathrm{Fi} \leq 30 \%$ and $\operatorname{rare}(\mathrm{R})=\mathrm{Fi} \leq 10 \%$ (Zhang, Gui, Liu, 2004). 

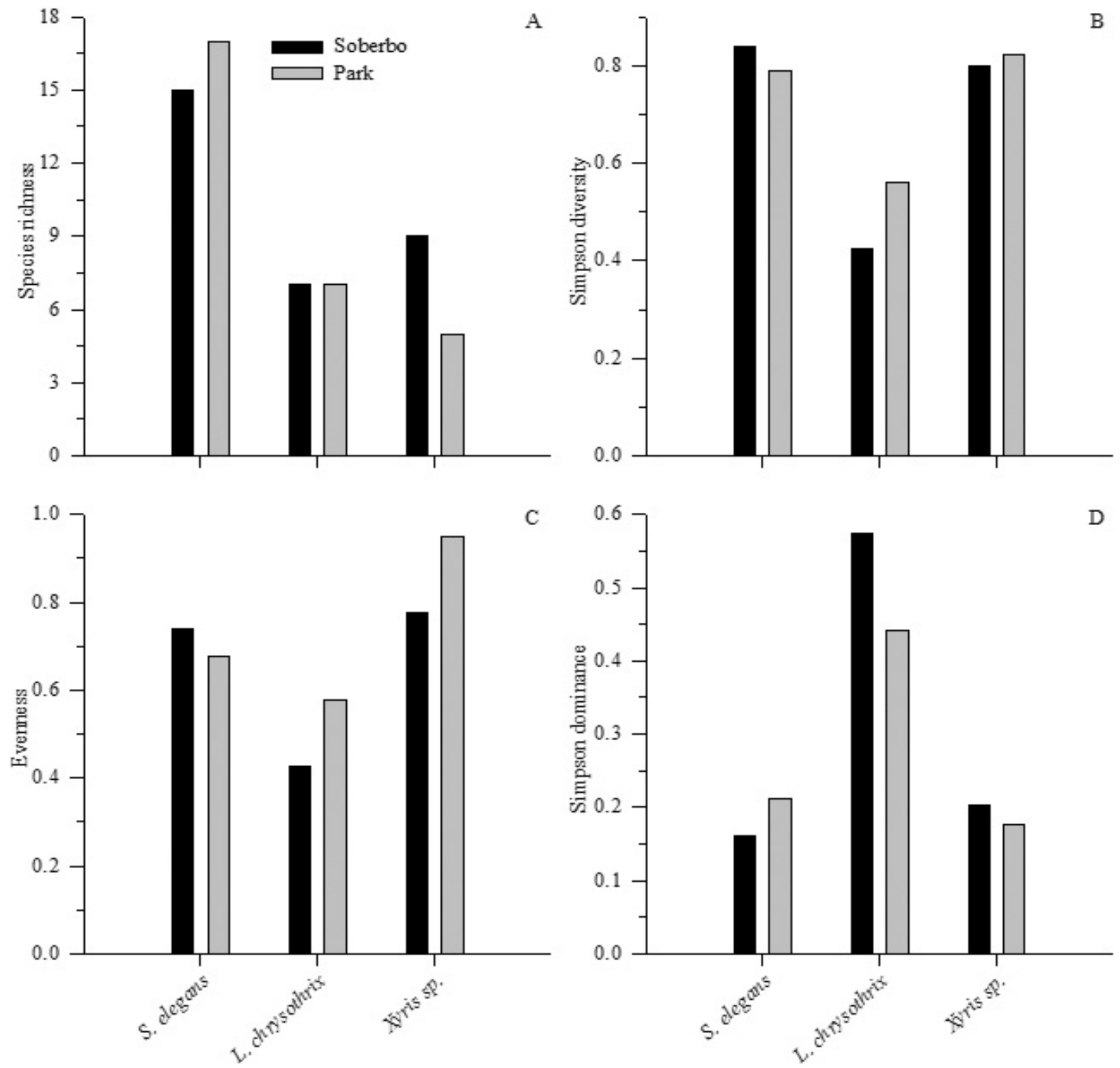

Figure 3: Species richness (a), Simpson diversity (b), Evenness (c) and Simpson dominance (d) of AMF communities associated with S. elegans $(n=10)$, L. chrysothrix $(n=3)$ and Xyris sp. $(n=3)$ at the Soberbo and Park sites

\section{CONCLUSIONS}

Based on the high levels of mycorrhizal colonization, Syngonanthus elegans is considered a mycotrophic host. Members of the main families and genera of Glomeromycota are associated with S. elegans in Rupestrian fields, although the identity of AMF species associated with this plant varied according to the area sampled. Trap cultures established using soils from Rupestrian fields represent an important strategy to complement AMF diversity assessment and help in the identification of field collected spores, as $30 \%$ of the total diversity was detected with this technique.

\section{ACKNOWLEDGMENTS}

We would like to acknowledge the National Counsel of Technological and Scientific Development 
$(\mathrm{CNPq})$ and Fundação de Amparo à Pesquisa do estado de Minas Gerais (FAPEMIG) for financial support and Coordenação de Aperfeiçoamento de Pessoal de Nível Superior (CAPES) for providing scholarships to CNPq for a research assistantship (Process number 302343/2012-1).

\section{REFERENCES}

BASHAN, Y. et al. Mycorrhizal characterization of the boojum tree, Fouquieria columnaris, an endemic ancient tree from the Baja California Peninsula, Mexico. Trees, 21(3):329335, 2007.

BORBA, M. F.; AMORIM, S. M. C. Fungos micorrízicos arbusculares em sempre-vivas: subsídio para cultivo e replantio em áreas degradadas. Revista de Biologia e Ciências da Terra, 7(2):20-27, 2007.

BROWER, J. E.; ZAR, J. H.; VON ENDE, C. N. Field and laboratory methods for general ecology. Dubuque, McGraw-Hill, 1998. 273p.

CARVALHO, F. et al. The mosaic of habitats in the high-altitude Brazilian Rupestrian fields is a hotspot for arbuscular mycorrhizal fungi. Applied Soil Ecology, 52:9-19, 2012.

CARVALHO, F. et al. Relationship between physical and chemical soil attributes and plant species diversity in tropical mountain ecosystems from Brazil. Journal of Mountain Science, 11(4):875-883, 2014.

CONCEIÇÃO, A. A.; PIRANI, J. R. Delimitação de habitats em campo Rupestres na Chapada Diamantina: substratos, composição florística e aspectos estruturais. Boletim de Botânica Universidade São Paulo, 23(1):85-111, 2005.

CONCEIÇÃO, A. A.; PIRANI, J. R. Diversidade em quatro áreas de campos rupestres na Chapada Diamantina, Bahia, Brasil: espécies distintas, mas riquezas similares. Rodriguésia, 58:193-206, 2007.

COSTA, F. N. Campos Rupestres. In: SILVA, A. C.; PEDREIRA, L. C. S. F.; ABREU, P. A. A. Serra do Espinhaço Meridional: Paisagens e Ambientes. Belo Horizonte: O Lutador, 2005. p. 139-145.

DUMBRELL, A. J. et al. Idiosyncrasy and overdominance in the structure of natural communities of arbuscular mycorrhizal fungi: is there a role for stochastic processes? Journal of Ecology, 98(2):419-428, 2010.

EMPRESA BRASILEIRA DE PESQUISA AGROPECUÁRIA EMBRAPA, Centro Nacional de Pesquisa de Solos. Sistema brasileiro de classificação dos solos. Rio de Janeiro: Embrapa Solos. 2006. 306p.
FERNANDA, C.; ECHEVERRÍA, H. E.; PAGANO, M. C. Arbuscular mycorrhizal fungi: essential belowground organisms for earth life but sensitive to a changing environment. African Journal of Microbiology Research, 6:5523-5535, 2012.

GERDEMANN, J. W.; NICOLSON, T. H. Spores of mycorrhizal endogone species extracted from soil by wet sieving and decanting. Transactions of the British Mycological Society, 46(2):235-244, 1963.

GIOVANNETTI, M.; MOSSE, B. An evaluation of techniques for measuring vesicular arbuscular mycorrhizal infection in roots. New Phytologist, 84(3):489-500, 1980.

GIULIETTI, A. M. et al. Estudos em sempre-vivas: taxonomia com ênfase nas espécies de Minas Gerais, Brasil. Acta Botânica Brasilica, 10(2):329-377, 1996.

GIULIETTI, A. M.; PIRANI, J. R.; HARLEY, R. M. Espinhaço range region, eastern Brazil. In. DAVIS, S. D. et al. (Eds.) Centres of plant diversity: a guide and strategy for their conservation. Oxford: Information Press, 1997, v.3, p. 397-404.

HOAGLAND, D. R.; ARNON, D. I. The water culture method for growing plants without soil. California Agricultural Experiment Station, 1950. 347p.

JOLY, A. B. Conheça a vegetação brasileira. São Paulo: Edusp/ Polígono, 1970. 165p.

KOSKE, R. E.; GEMMA, J. N.; FLYNN, T. Mycorrhizae in Hawaiian Angiosperms: a survey with implications for the origin of the native flora. American Journal of Botany, 79:853-862, 1992.

KOSKE, R. E.; GEMMA, J. N. Mycorrhizal status of two Hawaiian plant species (Asteraceae) in a tropical alpine habitat: the threatened Haleakal Silversword (Angyroxiphium sandwicense subsp. macrocephalum) and the endemic Dubautia menziesii. Pacific Science, 56(4):423-430, 2002.

LE STRADIC, S. et al. The role of native woody species in the restoration of Campos Rupestres in quarries. Applied Vegetation Science, 17(1):109-120, 2014.

LE STRADIC, S.; BUISSON, E.; FERNANDES, G. W. Restoration of neotropical grasslands degraded by quarrying using hay transfer. Applied Vegetation Science, 17(3):482-492, 2014.

MAGURRAN, A. E. Ecological diversity and it's measurement. Springer Science and Business Media. 1988. 179p.

MARRA, L. M. et al. Diazotrophic bacteria in star flowers. Bioscience Journal, 28(1):17-24, 2012.

MENEZES, N. D.; GIULIETTI, A. M. Campos rupestres. In: Lista Vermelha das Espécies Ameaçadas de Extinção da Flora de Minas Gerais. Fundação Biodiversitas, Fundação Zoo-Botânica de Belo Horizonte, Belo Horizonte, 2000. p. 95-63. 
MIRANDA, E. B.; GIULIETTI, A. M. Eriocaulaceae no Morro do Pai Inácio (Palmeiras) e Serra da Chapadinha (Lençóis), Chapada Diamantina, Bahia, Brasil. Sitientibus Série Ciências Biológicas, 1(1):15-32, 2001.

NEVES, S. C.; ABREU, P. A. A.; FRAGA L. M. S. Fisiografia. In: SILVA, A. C.; PEDREIRA, L. C. V. S. F.; ABREU, P. A. A. Serra do Espinhaço Meridional: Paisagens e ambientes. Belo Horizonte: O Lutador, 2005. 272p.

NUNES, S. C. P. et al. Época, local de colheita e armazenamento na qualidade fisiológica da semente de sempre-viva (Syngonanthus elegans (Bong.) Ruhland-Eriocaulaceae). Revista Brasileira de Sementes, 30(1):32-39, 2008.

OEHL, F. et al. Acaulospora alpina, a new arbuscular mycorrhizal fungal species characteristic for high mountainous and alpine regions of the Swiss Alps. Mycologia, 98(2):286-294, 2006.

PAGANO, M. C.; SCOTTI, M. R. A survey of the arbuscular mycorrhiza occurrence in Paepalanthus bromelioides and Bulbostylis sp. in Rupestrian fields, Brazil. Micologia Aplicada Internacional, 21:1-10, 2009.

PAGANO, M. C.; CABELLO, M. N. Mycorrhizas in natural and restored riparian zones. In: Mycorrhiza: Occurrence in natural and restored environments. Hauppauge (NY): Nova Science Publishers. 2012. 327p.

PHILLIPS, J. M.; HAYMAN, D. S. Improved procedures for clearing roots and staining parasitic and vesicular mycorrhizal fungi for rapid assessment of infection. Transactions of the British Mycological Society, 55(1):158-161, 1970.

POWERS, J. S.; TRESEDER, K. K.; LERDAU, M. T. Fine roots, arbuscular mycorrhizal hyphae and soil nutrients in four neotropical rain forests: patterns across large geographic distances. New Phytologist, 165(3):913-921, 2005.

REDECKER, D. et al. An evidence-based consensus for the classification of arbuscular mycorrhizal fungi (Glomeromycota). Mycorrhiza, 23(7):515-531, 2013.

SAGGIN JÚNIOR, O. J. et al. Colonização do cafeeiro por diferentes fungos micorrízicos: efeitos na formação das mudas e crescimento em solo fumigado. Revista Brasileira de Ciência do Solo, 19(2):213-220, 1995.

SCATENA, V. L.; MENEZES, N. L. Anatomia de raízes de Syngonanthus Ruhl. (Eriocaulaceae). Revista Brasileira de Biologia, 56:333-343, 1996a.

SILVA, G. A. et al. Arbuscular mycorrhiza in species of Commelinidae (Liliopsida) in the state of Pernambuco (Brazil). Acta Botânica Brasilica, 15(2):155-165, 2001.
SILVEIRA, S. V. D.; SOUZA, P. V. D. D.; KOLLER, O. C. Influence of arbuscular mycorrhizal fungi on vegetative growth of avocado rootstocks. Pesquisa Agropecuária Brasileira, 37(3):303-309, 2002.

SOIL SURVEY STAFF Departament of Agriculture. Soil Survey Division. Soil Conservation Service. Soil Taxonomy: A Basic System of Soil Classification for Making and Interpreting Soil Surveys, USDA Washington, SC, 1999.

SOUZA, F. A. et al. Classificação e taxonomia de Fungos Micorrizicos Arbusculares e sua diversidade e ocorrência no Brasil. In: SIQUEIRA, J. O.; DE SOUZA, F. A.; CARDOSO, E. J. B. N.; TSAI, S. M. Micorrizas $\mathbf{3 0}$ anos de pesquisa no Brasil. UFLA, Lavras, 2010. p. 1-14.

STÜRMER, S. L.; SIQUEIRA, J. O. Diversidade de fungos micorrízicos arbusculares em ecossistemas brasileiros. In: Biodiversidade do solo em ecossistemas brasileiros. UFLA, Lavras, 2008. p. 537-583.

STÜRMER, S. L.; SIQUEIRA, J. O. Diversity of arbuscular mycorrhizal fungi in brazilian ecosystems. In: MOREIRA, F. M. S.; SIQUEIRA, J. O.; BRUSSAARD, L. Soil biodiversity in amazonian and other brazilian ecosystems. CABI Publishing, London, 2006. p. 206-236.

STÜRMER, S. L. Evolução, classificação e filogenia dos fungos micorrízicos arbusculares. In: Siqueira, J. O. et al. Interrelação fertilidade, biologia do solo e nutrição de plantas. Sociedade Brasileira de Ciência do Solo, Lavras, 1999. p. 97-817.

STUTZ, J. C.; MORTON, J. B. Successive pot culture reaveal high species richness of arbuscular endomycorrhizal fungi in arid ecosystems. Canadian Journal of Botany, 74(12):1883-1889, 1996.

TRESEDER, K. K. A meta-analysis of mycorrhizal responses to nitrogen, phosphorus, and atmospheric $\mathrm{CO}^{2}$ in field studies. New Phytologist, 164(2):347-355, 2004.

VIEIRA, J. P. G. et al. Estudo da precipitação mensal durante a estação chuvosa em Diamantina, Minas Gerais. Agriambi, 14(7):762-767, 2010.

ZAPPI, D. C.; TAYLOR, N. P. Flora de Grão-Mogol, Minas Gerais: cactaceae. Boletim de Botânica da Universidade de São Paulo, 21:147-154, 2003.

ZHANG, Y.; GUI, L. D.; LIU, R. J. Survey of arbuscular mycorrhizal fungi in deforested and natural forest land in the subtropical region of Dujiangyan, southwest China. Plant Soil, 261(1-2):257-263, 2004. 